\title{
SOVIETINIŲ METŲ GYVENAMIEJI RAJONAI VILNIUJE: TIPIŠKUMO PROBLEMA
}

\author{
Indrė Ruseckaitė \\ Architektūros pagrindų ir teorijos katedra, Vilniaus Gedimino technikos universitetas, \\ Pylimo g. 29/Traku g. 1, 01132 Vilnius, Lietuva \\ El.paštas ruseckaite.indre@gmail.com
}

Iteikta 20101116

Santrauka. Straipsnyje nagrinejjami Karoliniškių, Viršuliškių ir Šeškinės gyvenamieji rajonai Vilniuje, išskiriant ir apibūdinant kelis svarbiausius bruožus, leidžiančius teigti, jog šių rajonų urbanistinės-architektūrinès charakteristikos tarpusavyje skiriasi ir dèl to šios urbanistinès struktūros nèra tipinès. Analizuojama, kokie buvo rajonus projektavusių architektų kūrybiniai siekiai formuoti individualius rajonų urbanistinius-architektūrinius charakterius; kodèl šie rajonai buvo kritikuoti ir kaip ị tai reaguojant kito urbanistiniai-architektūriniai sprendimai; kaip atnaujinant sovietinio laikotarpio gyvenamuosius rajonus kinta saviti jų požymiai.

Reikšminiai žodžiai: sovietiniai metai, masinè statyba, tipiniai pastatai, monolitiniai aukštybiniai gyvenamieji pastatai.

\section{İvadas}

Šeštajame dešimtmetyje Tarybų Sąjungoje prasidèjo masinès industrializuotos gyvenamųjų pastatų statybos, kai miestuose atsirado naujų urbanistinių struktūrų. Formuojami nauji gyvenamieji rajonai to meto mokslineje ir profesineje spaudoje buvo kritikuoti dèl urbanistinès ir architektūrinès monotonijos bei tarpusavio supanašèjimo, ir tai buvo būdinga problema visoje buvusios Tarybų Sąungos teritorijoje, nes nauji miegamieji rajonai buvo formuoti visuose miestuose (Аникеев, Новиков 1978; Полторацкий 1977; Jaralovas 1979; Balčiūnas 1977). Vilniuje iki 10-ojo dešimtmečio pradžios apie $19 \mathrm{kv}$. km plotas buvo užstatytas sovietiniu laikotarpiu vadinamaisiais „naujaisiais rajonais“. Šiandien jie vadinami tipiniais beveidžiais miegamaisiais, pilkuoju socmodernizmo veidu. Visgi platus pripažinimas, apdovanojimai už Lazdynų ir Žirmūnų rajonų suplanavimą, jų ịtraukimas ị urbanistinių paminklų sąrašus neleidžia beatodairiškai taikyti šablono „tipinis“ ir kitiems sovietiniu laikotarpiu formuotiems gyvenamiesiems rajonams. Straipsnyje siekiama atsakyti i klausimus, kokie buvo rajonus projektavusių architektų kūrybiniai siekiai formuoti individualius rajonų urbanistinius ir architektūrinius charakterius; kodèl šie rajonai buvo kritikuoti ir kaip ị tai reaguojant kito urbanistiniai-architektūriniai sprendimai; kokie požymiai leistų teigti, jog šie rajonai nèra tipiniai; kaip po $2000 \mathrm{~m}$. atnaujinant sovietinio laikotarpio gyvenamuosius rajonus šie požymiai kinta; niveliuoja ar ryškina šie pokyčiai jų pirminius charakteringus bruožus.

7-ojo dešimtmečio pabaigoje pradedamos formuoti gyvenamųjų rajonų teritorijos Laisvès (buv. Kosmonautų) prospekto aplinkoje, iš jų Lazdynai buvo ir pirmasis, ir etaloninis rajonas. Vèliau suformuoti dar septyni nauji gyvenamieji rajonai, iš kurių pirmieji trys - Karoliniškès, Viršuliškès ir Šeškinè - taip pat svarbūs tiek urbanistikos ir architektūros požiūriu, tiek ir todèl, kad būtent juose ryškiausiai atsiskleidžia gyvenamųjų rajonų formavimo raida. Tai savotiški chrestomatiniai pavyzdžiai, kuriuos galima iliustruoti: 1) 7-ajame dešimtmetyje ir 8-ojo dešimtmečio pradžioje ieškota originalių rajonų suplanavimo sprendimų naudojant tuos pačius tipinès architektūros pastatus, kiekviename rajone juos savitai komponuojant erdvejje, pastatus ir aplinką marginant ornamentais, būdingais tik vienam rajonui (Karoliniškèse ir Viršuliškèse); 2) susidūrus su urbanistine monotonija bei su jos kritika, pradedami keisti tipinès architektūros erdviniai parametrai (pir- 
moji namų grupė Viršuliškèse ir visas Šeškinès rajonas); 3) siekiant išvengti naujo pobūdžio urbanistinès ir architektūrinès monotonijos 8-ojo dešimtmečio pabaigoje gyvenamujjų rajonų identitetas ir originalus charakteris pradètas kurti specialiai jiems projektuojamais aukštybiniais monolitiniais akcentais (Šeškinè).

\section{Lazdynų gyvenamojo rajono formavimo bruožai ir jų ịtaka kitų Vilniaus gyvenamųjų rajonų projektavimui}

Kai 1955 m. atsisakoma „retrospektyvinių nesaikingumų" ir $1957 \mathrm{~m}$. Vyriausybei priemus nutarimą „<...> Dèl gyvenamujų namu statybos išvystymo Tarybu Sajungoje, kuriuo buvo iškelta užduotis per 10-12 metu likviduoti butų trūkumą" (Miškinis 1991), 1959 m. pagal kiek pakoreguotą tipinį sajunginị projektą Vilniuje pastatomi pirmieji stambiaplokščiai namai - taip pradedama masinè industrinè namų statyba. Straipsnyje tiriami keli Vilniaus miegamieji rajonai, kurie ir buvo suprojektuoti bei realizuoti prasidejus industrinès statybos bangai, t. y. 1963-1980 m. periodu, kai iki 1980 m. galiojo 1967 m. patvirtintas Generalinis miesto planas. Pagal ji šiaurès vakarineje miesto dalyje numatyta formuoti naujuosius gyvenamuosius rajonus (1 pav.). Dar prieš naujaji miesto plètros etapą savotiškas lūžis planavimo srityje ịvyko suprojektavus ir pastačius Žirmūnų rajoną bei gavus svarbų sąjunginị apdovanojimą už jo suplanavimą. Tai paskatino Lietuvos urbanistus ir architektus, net ir íspraustus ị reglamentuojančių aplinkybių bei tipinių stambiaplokščiu pastatų rẻmus, ir toliau siekti kiekvienam naujai projektuojamam rajonui suteikti savitą urbanistini charakterị. Taigi pradedama etapiškai projektuoti bei statyti naujus rajonus aplink naująją Vilniaus dalies aši - Kosmonautų (dab. Laisvès) prospektą. Pirmasis iš jų - Lazdynų rajonas, suprojektuotas 1962 m., statytas 1963-1973 m. 1974 m. jų autoriai Vytautas Brédikis, Vytautas Edmundas Čekanauskas ir kiti už šio rajono suprojektavimą gavo Lenino premiją bei buvo plačiai Sąungoje pripažinti. Tai buvo pirmasis atvejis Tarybų Sąungoje, kai tokios svarbos apdovanojimas paskirtas už gyvenamojo rajono suprojektavimą ir igyvendinimą. Taigi pirmasis Kosmonautu prospekto rajonas ivvertinamas maksimaliai aukštai ir iš tolesnius rajonus (Karoliniškių, Viršuliškių ir Šeškinès) projektuosiančių architektų tikètasi ,juos sukurti taip pat gerai kaip Lazdynus, o gal net ir geriau“ (Сакалаускас 1974).

Plačiai pripažinti ir garsūs Lazdynai iš karto, kai buvo suprojektuoti ir gavo apdovanojimą, tapo etalonu ir kitiems naujiesiems rajonams projektuoti. Nuo 1974 m. pradèta juos analizuoti, siekiant atsakyti i klausimą „kur glūdi progresyvios kūrybos esmë“ (Jaralovas 1975). Išskiriami tokie sektini bruožai kaip išsami anali-

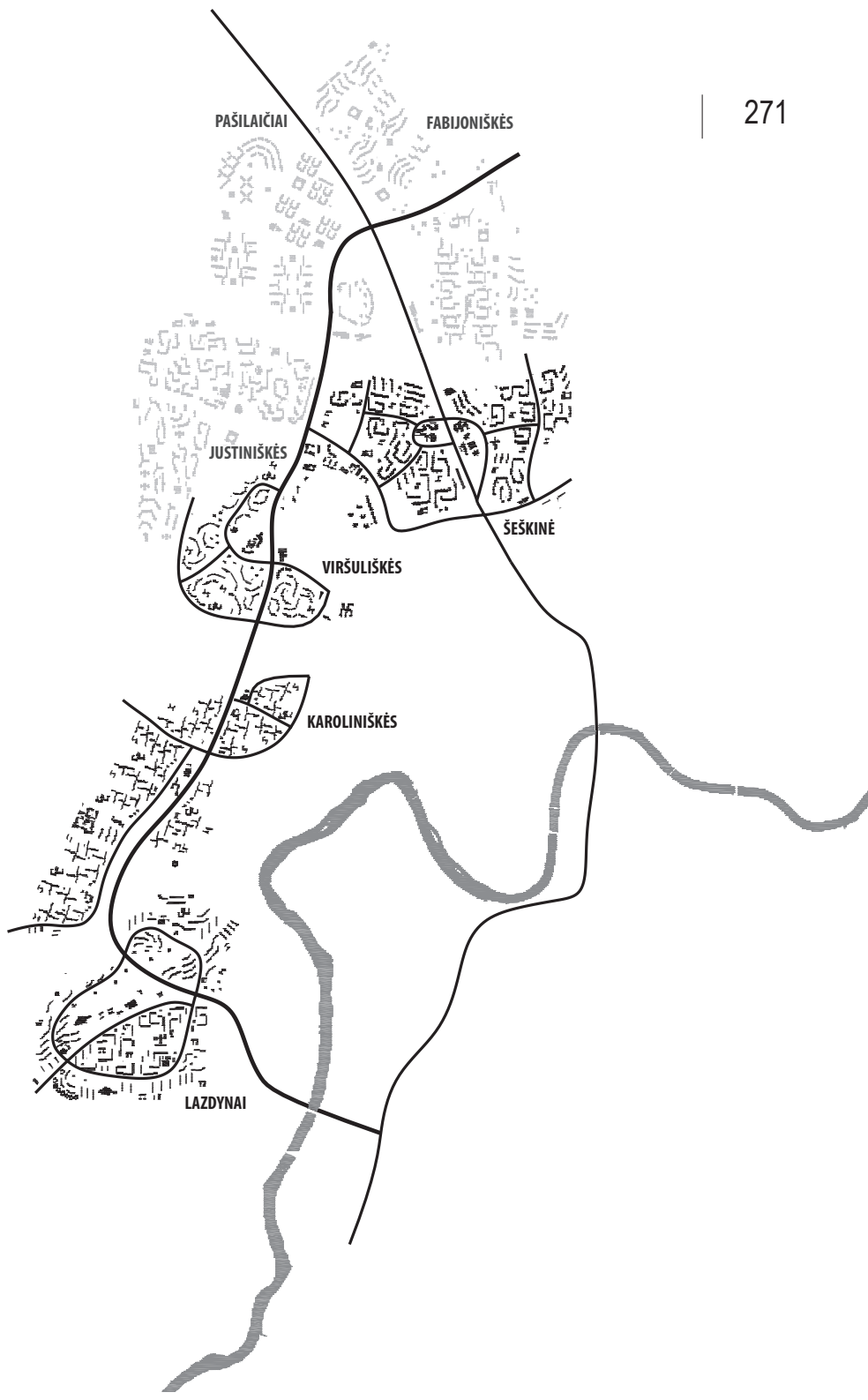

1 pav. Gyvenamujų rajonų aplink Laisvès (buv. Kosmonautų) prospektą plano schema (schema autorès)

Fig. 1. Scheme of residential distrcicts along Laisvè Av.

zè nagrinèjant buvusią ir būsimą erdvinę kompozicinę Vilniaus sandarą, kraštovaizdị ir gamtinę aplinką. Pasak V. Mikučianio (Mikučianis 1974), prieš pradėdami projektuoti Lazdynų mikrorajoną autoriai studijavo ne tik Tarybų Sąjungos architektų kūrybinę patirtį formuojant naujuosius gyvenamuosius rajonus, juos taip pat veikè Suomijos Tapiola modernistinio miesto pavyzdys (Микучанис 1974). Taip pat Švedijos Vällingby, Prancūzijos Tolouse-Le Miraile nauji urbanistiniai sprendimai (Dremaite 2010). Lazdynų sèkmès pagrindu laikytas meistriškumas ịvertinant visus sudètingo reljefo kompozicinius privalumus, sudariusius architektams plačias kūrybines galimybes komponuoti keliolikos rūšių tipinių gyvenamųjų pastatų tūrius. Ryškiais architektūriniais savitumais pasižyminčiuose miestuose plètojamos naujos teritorijos turètų „būti formuojamos pagal bendruosius kūrybinius principus, pratęsiant jau suformuotose miesto dalyse išryškëjusius bruožus. $<$...> Pavykęs naujosios architektūros kūrimo pavyzdys 

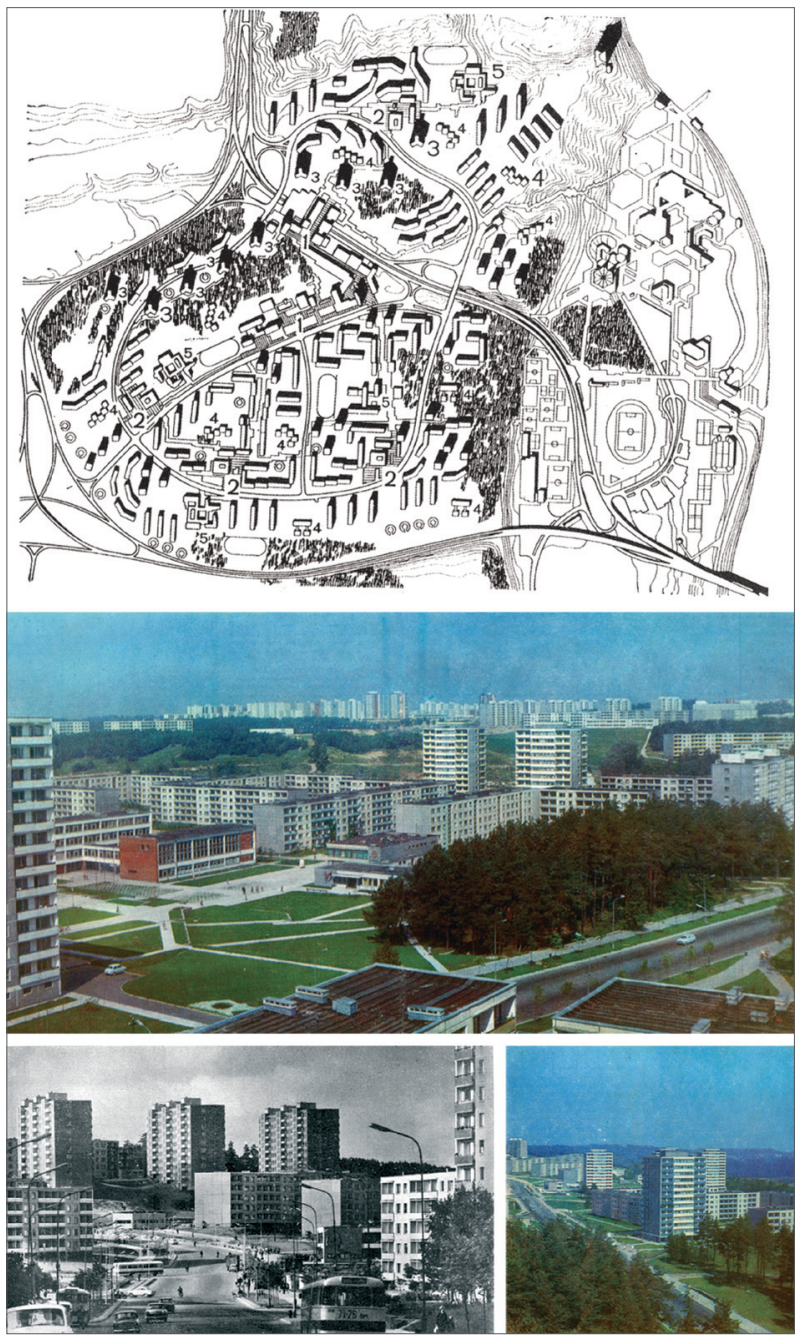

2 pav. Lazdynu rajono planas (1962 m.), arch. V. Brèdikis, V. E. Čekanauskas. Rajono vaizdai 1974 m. (Архитектура CCCP, 11/1974)

Fig. 2. Plan of Lazdynai district (1962) - arch. V. Brèdikis, V. E. Čekanauskas. View of Lazdynai in 1974

<...> - Lazdynai“ (Miškinis 1982). Pasak autoriaus, tai nauja, ne scheminè, organiškai su aplinka deranti gyvenamojo rajono architektūra, turinti sąsajų su Vilniaus senamiesčiui būdingais bruožais. Pasak J. Vanago, ypatingo dèmesio vertas Lazdynu plano ir erdvès sprendinių vientisumas ir darnumas; visas gyvenamasis masyvas formuoja nedalomą visumą, kurios mikrorajonai nèra dirbtinai atskirti. Pačių autorių sumanymu rajonas turi būti greičiau utilitarus ir funkcionalus, o ne savitiksle kompozicija. Taip pat siekta rajonui suteikti savitą ir ịvairų vilnietišką veidą, todèl formuota miesto senamiesčiui būdinga silueto dinamika, susiliejančių erdviu sistema, jaukios, palyginti nedidelès kiemų erdvès (Ванагас 1974). Vilnietiški bruožai būdingi ir kalbant apie rajono dydžių santykius. „Lazdynų gyvenamojo rajono plano struktūroje vieningai išlaikytas užstatytų teritorijų skaidymas gatvemis ir pèsčiųjų alëjomis tuo pačiu moduliu kaip ir Vilniaus istoriniame branduolyje. Taip išlaikytos vienodos proporcijos atskirose miesto dalyse, kas yra būtina sąlyga formuojant naujus rajonus" (Шешельгис 1974). Rajono erdvumas, tinkamas užstatytos ir laisvos teritorijos santykis įspūdingame gamtiniame kontekste taip pat ivardijamas kaip vienas iš pagrindinių Lazdynų privalumų (Яралов 1974). Taigi šie Lazdynų bruožai tapo siekiu kuriant ir kitus Vilniaus naujuosius gyvenamuosius rajonus (2 pav.) Tačiau kiti rajonai turèjo būti projektuojami ne tokioje unikalioje gamtinèje aplinkoje, kur reljefas padètų kūrybai. Taip pat 7-ojo dešimtmečio pabaigoje keitėi užstatymo intensyvumo normos, todèl minètasis Lazdynų erdvumo bruožas negali būti iggyvendintas kituose rajonuose, kurių pirmasis - Karoliniškès.

\section{Kai kurie Karoliniškių ir Viršuliškių gyvenamųjų rajonų formavimo ypatumai}

Karoliniškių gyvenamojo rajono suplanavimo kūrybinè komanda, vadovaujama architekto K. Balèno, 7-ojo dešimtmečio pabaigoje pradèjo projektavimo darbus, kurie sulaukè didelio dèmesio to meto profesineje spaudoje. Šiuose šaltiniuose taip pat fiksuojamas pačių rajono suplanavimo autorių kūrybinis sumanymas. Autoriai ivardija siekius ir priemones, padessiančius originaliai formuoti rajoną. Naujasis Karoliniškių rajonas statomas ant pustrečio kilometro ilgio 200 ha ploto plokštikalnio tarp Neries ir Sudervèlès slènių (3 pav., a). Šiam rajonui numatytos teritorijos reljefas plokščias, todèl, viena vertus, gamtinè aplinka nepaveikta urbanistų ir architektų kūrybinių užmojų; kita vertus, neįmanoma kartoti Lazdynų stipriųjų bruožų, nes vienas iš svarbiausių - raiškus reljefas kaip sudetinè kompozicijos dalis - eliminuojamas. Todèl kuriant rajono siluetą, siekta „ivairių aukščiu pastatais uždèti plokštikalniui viršūnę" (Balènas 1970). Pastatų kaip kalvų piku turejjo tapti Vilniaus televizijos bokštas.

Analizuojant Karoliniškių suplanavimo projekto medžiagą, šiandienini šio rajono planą, akivaizdus kryžiaus motyvas urbanistiniame rajono ornamente. Charakteringa pastatu grupavimo forma naudojama visuose Karoliniškių mikrorajonuose. Tyrinejjant Vilniaus miesto planą, Karoliniškès - aiškiai identifikuojamas atskiras Laisvès prospekto segmentas ${ }^{1}$. Dèl kryžminio

\footnotetext{
${ }^{1}$ Formuojant Laisvés prospekto aplinką, gyvenamųjų rajonų masyvas planuotas remiantis istorinès Vilniaus raidos ypatumais, kurie „, $<\ldots>$ reiškèsi tuo, kad kiekviena senojo miesto dalis kūrèsi už natūraliu gamtos barjerų" (Miškinis 1991). Taigi kiekvienas naujas rajonas vienas nuo kito atskiriamas žaliuoju masyvu, o tai plane tampa savotiška rajono riba.
} 


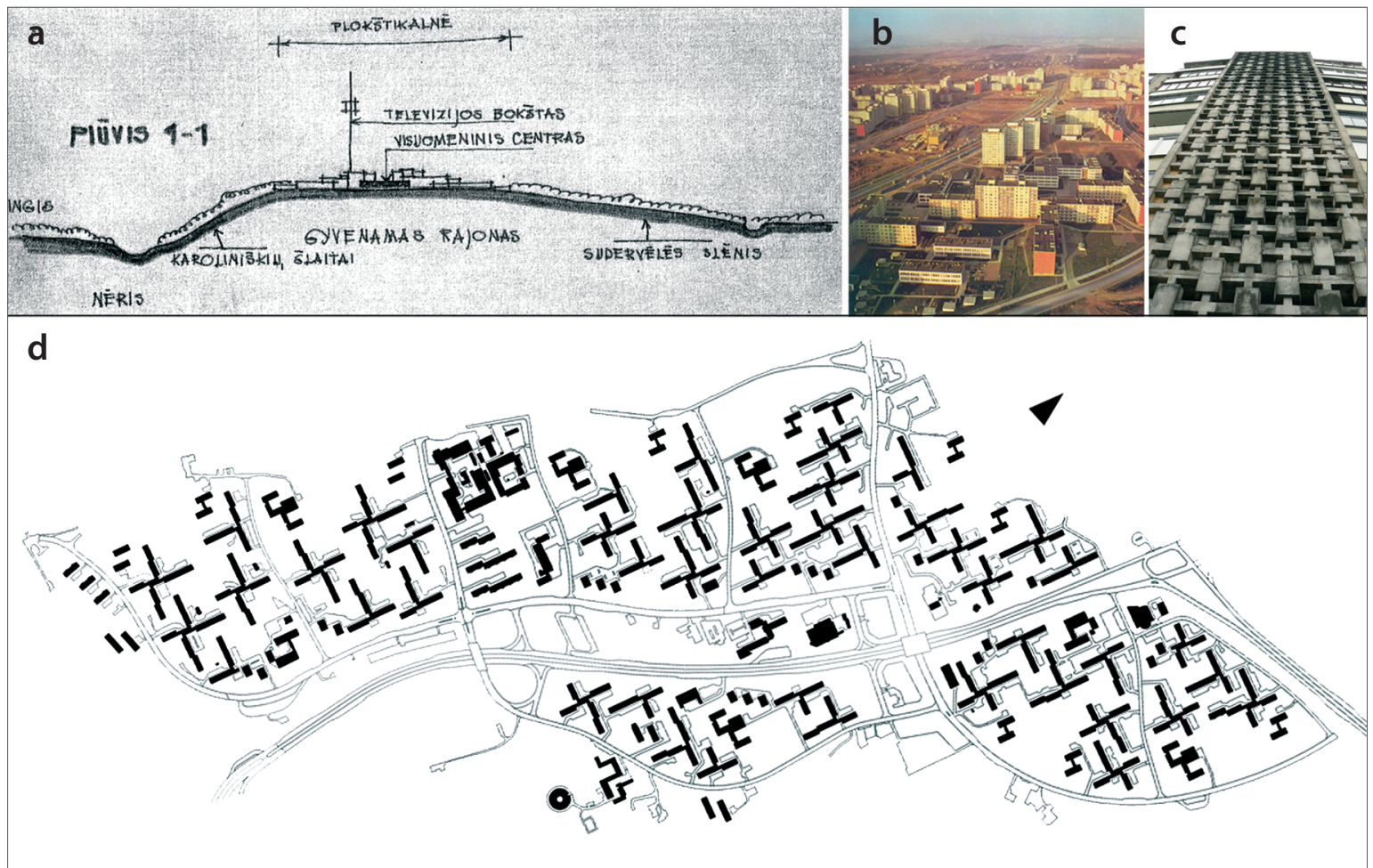

3 pav. Karoliniškių rajono skersinio pjūvio schema (Balènas 1970) (a); rajono vaizdas iš Televizijos bokšto (b); fasado dekoro fragmentas (c); rajono planas (d)

Fig. 3. Section scheme of Karoliniškès district (a); view from the TV Tower (b); detail of facade decor (c); plan of Karoliniškès district (d)

pastatų grupių jungimo, pasak autorių, „kaip niekur kitur Lietuvoje, originaliai išryškès namų blokavimas ir jo privalumai, kas padès sukurti pusiau uždaras erdves, originalius kiemus, susijungiančius ị savotišką kiemų zoną, ir padès išvengti dirbtinių skersvejjų“ (Balènas 1970). 7-ajame dešimtmetyje pasikeitus projektavimo normoms naujai formuojamame rajone užstatymas koncentruojamas kur kas labiau nei Žirmūnuose ir Lazdynuose, todèl ir rajono tankumas, jo urbanistinio ornamento intensyvumas daro jị išskirtini, tačiau tai yra ir antroji neatitiktis Lazdynų erdvumo bruožui. Karoliniškès formuotos naudojant tipinius pastatus taip, kad jie galètu tarpusavyje jungtis ị kryžiaus formos gyvenamujų namų grupes (3 pav., d). Statmenų linijų sankirtoje formuojamas aukščiausias pastatas, arba vadinamoji kalva, kurios tematiką ir plètoja autoriai. Projekte pastatų ugniasienes numatyta dažyti tamsiai raudona spalva, kuri padetų dar labiau pabrèžti rajono charakterị (tuo metu tai buvo pirmasis rajonas Vilniuje, kuriame tokiu mastu taikytas toks ryškus spalvinis sprendimas). Pastatų grupavimo principo tema kartojama ir rajono erdviniuose dekoratyviniuose ornamentuose. Laiptinių balkonų ažūrinès sienutès, kurios yra vienos iš skiriamųjų rajono ženklų, formuojamos audžiant stambesnių ir smulkesnių „pliu- sų " betonini raštą ( 3 pav., c); tokiais ažūrais dengiamos devynių aukštų pastatų laiptinès, todèl šios vertikalios plokštumos dominuoja erdvių formantuose ir sudaro savotišką identifikacinių ženklų sistemą visame rajone. Balkonų spalvos žymi atitiktį vienai ar kitai mikrorajono subzonai. Pastatų blokavimas specifine forma ir ryškus jų spalvinis sprendimas, architektūros dekoro elementai rajono suplanavimo autorius ịpareigojo akcentuoti, kad „Karoliniškių architektūra reikalauja gero atlikimo. Kitu atveju ji gali smarkiai nukenteti, ir rajonas neteks savito veido, kurio tikisi visi - nuo projektuotojų iki būsimųjų gyventojų“ (Balėnas 1970). Tačiau ịsibėgejjus statyboms ${ }^{2}$ spaudoje demesys ilgainiui krypo tik i jose statomą Televizijos bokštą (Balènas 1975).

Baigiant statyti Karoliniškes, ịsibejgejo Viršuliškių rajono suplanavimo darbai, kuriuos renge jungtine architektų B. Kasperavičienès, J. Zinkevičiaus, A. Bražinsko komanda apie 1975 m. Rajono teritorijos reljefas labiau

${ }^{2}$ Tai, kad rajono projektavimas ir statybos tapo svarbiu ir daugelio stebimu ịvykiu, iliustruoja 8-ojo dešimtmečio publikacijose aptinkami gyventoju pasiūlymai dèl naujojo rajono pavadinimo. Pasak jų, pavadinimas neturi kontekstualios sąsajos su šios teritorijos praeitimi, todèl siūloma jam suteikti Šaltūnu, buvusio kaimo Karoliniškių rajono teritorijoje, pavadinimą (Čyžius, Vanagas 1970). 


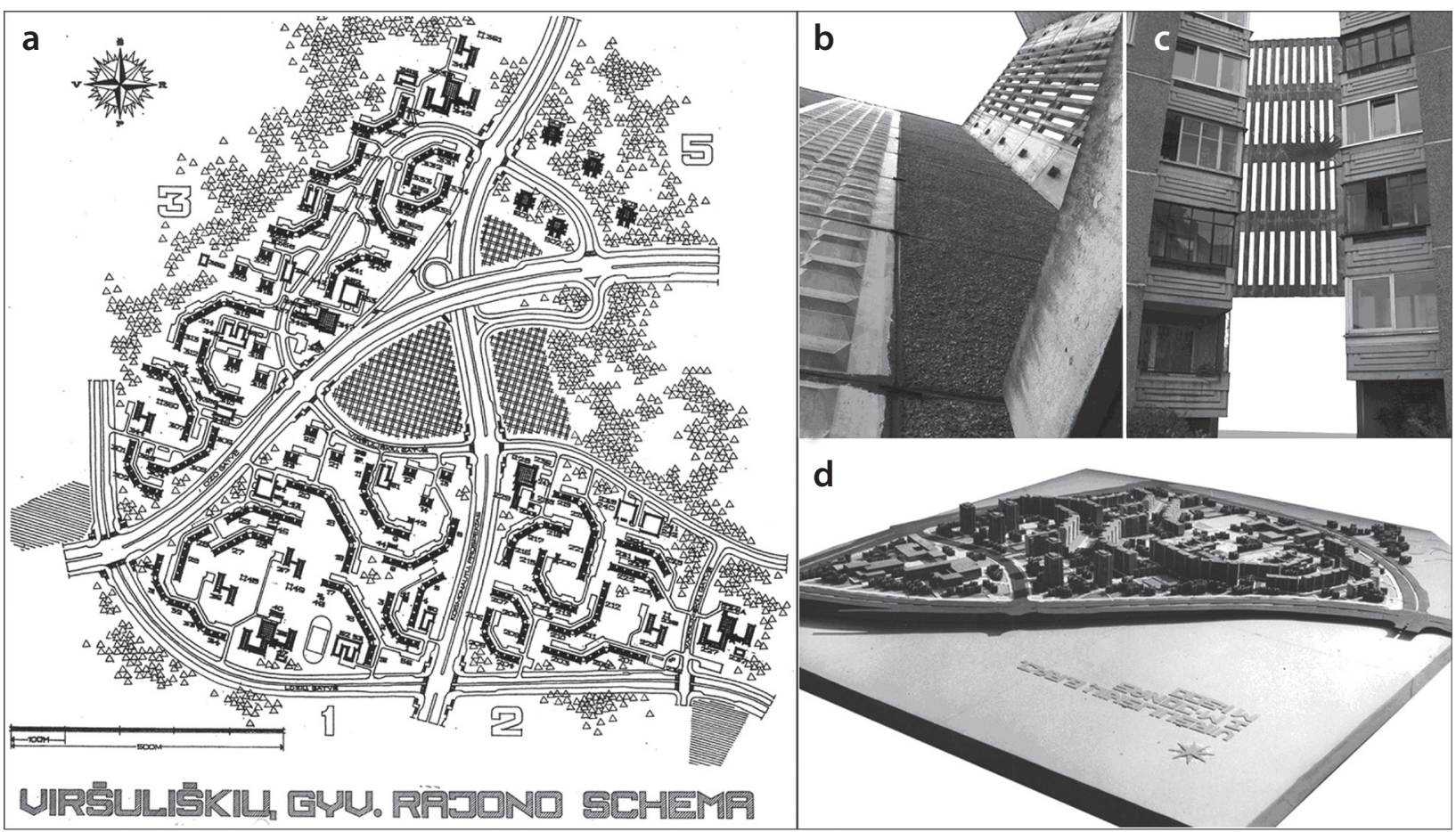

4 pav. Viršuliškių rajono planas (a); fasado dekoro fragmentas (b); 120V serijos namy jungimas ankstesnio periodo detale (c); Viršuliškiu I-ojo mikrorajono maketas (d)

Fig. 4. Plan of Viršuliškès district (a); detail of facade decor (b); serial $120 \mathrm{~V}$ buildings combined by the prior stage architectural detail (c); model of the Ist microdistrict of Viršuliškès (d)

kalvotas nei Karoliniškių. Šiame kontekste rajonas suplanuotas tos pačios serijos gyvenamuosius namus, kurie naudoti statant Karoliniškes ir Lazdynus, jungiant i lanko formos grupes (4 pav., a, d). Lanko motyvas kartojamas visuose trijuose Viršuliškių mikrorajonuose. Pastatai ị laužytos konfigūracijos grupes jungiami neblokuojant - jungtimi tampa ažǔrinès plokštès. Šio elemento ornamentinè tema, pasak pačių autorių, tai vertikalių lygiagrečių linijų (išpjovimų) metras arba tiesiog „termometras“ (4 pav., b). Taip jungiant pastatus norèta suteikti skaidrumo, pagerinti oro cirkuliaciją vidinèse mikrorajono erdvėse; šių plokščiu apačioje formuojamos užuovejjos kartu su savotiškais namų grupių viešaisiais taškais. Šiandien ne tik „termometro“ motyvas identifikuoja rajoną; Viršuliškèse namų jungtis patys gyventojai naudoja kaip adresų knygas, kur kiekvieno namų bloko aktualijos ir identifikaciniai šūkiai leidžia atpažinti zonas. „Termometro“ tema taip pat naudojama laiptinių ažūre; o ugniasienès ir balkonai dekoruoti „prizmių“ struktūra. Pirminiame projekte Viršuliškių pastatus numatyta dažyti skirtingomis spalvomis priklausomai nuo jų aukščio. Visgi tgyvendintas lakoniškas šviesiu atspalvių sprendimas, todèl dar labiau išryškejja skulptūriški rajono fasadų reljefai. Būtų galima teigti, kad Viršuliškių identifikacinị rinkinị ir sudaro vientisa rajono urbanistinių „lankų“ sistema plane bei charakteringi skulptūriški elementai erdvèje.

\section{Gyvenamųjų rajonų monotonijos kritika}

„Kam iš vilniečių neteko girdèti kritikos apie Karoliniškes - naują gyvenamąjị rajoną, išaugusị Lazdynų šešèlyje? <...> Suprantama, gimti po Lazdynu nepavydètina, koks tas naujagimis bebūtų. Bet kur kas svarbiau tai, kad kol kas Karoliniškès išties negali optimistiškai nuteikti“" (Budrys 1976). Dar nebaigus statyti Karoliniškių pradedamas kelti klausimas, kokios naujojo rajono nesèkmių priežastys. Jų ịvardijama keletas: 1) viena svarbiausių - tai reljefas, kuris Karoliniškèse daug skurdesnis, ir tai nepadèjo komponuojant tipinius pastatus; 2) rajonas be galo klaidus - nors ir originalios, bet visame rajone vienodos pastatu grupés formuoja identiškas kiemų erdves. Erdvių diferenciacija aiškesne artejjant link mikrorajonų centrų. Tačiau orientavimasis mikrorajono viduje sudètingas; 3 ) nesusikalbejjimas tarp projektuotojų ir statybininkų smarkiai paveikè statybų kokybę bei projekto ir realizacijos neatitikimą. Kūrybinès Karoliniškių komandos akcentuota sąlyga, jog rajono architektūra reikalauja gero atlikimo tam, kad rajonas neprarastų jam sukurto charakterio, neịgyvendinama; 4) per didelis rajono užstatymo tanku- 
mas. Po šių publikacijų tendencingai pradeda nykti kitų naujujjų rajonų projektų ir realizacijų aprašymų kiekis tuometineje spaudoje, tik pavienès fragmentiškos žinutès apie Viršuliškes, Šeškinę, ir kol kas sunku rasti informacijos apie tų rajonų pirminius projektus, pačių autorių komentarus apie kūrybinius siekius ${ }^{3}$.

8-ajame dešimtmetyje prasideda arši architektų kritika, skirta masinei statybai tiek Lietuvoje, tiek ir visoje Tarybų Sajungoje. Iš daugelio to meto publikacijų ima ryškèti savotiškas suvokimo lūžis, kad nebei̇manoma sukurti originalių miesto dalių naudojant tas pačias industrinès masinès statybos priemones, nes vis tiek tai bus kažkur matyta ir tipiška (Jaraliovas 1979). Gyvenamųjų rajonų urbanistinès monotonijos ir architektūrinès išraiškos problemos buvo dažna to meto profesinès spaudos tema. To priežastys įvardijamos kelios. Pirma - tai ilgalaikis ir neribotas vienų ir tų pačių tipinių projektų kartojimas, pvz., Vilniuje nuo 1966 m. Žirmūnų rajonas formuotas statant 1-646LT serijos gyvenamuosius namus, 1967 m. ši serija keičiama ị 1-646LI ir naudota komponuojant Lazdynų rajoną. Karoliniškès, Viršuliškès, Baltupiai taip pat formuojami naudojant ši pastatų tipą, nors ir su nedideliais pakeitimais, reikalingais ịvairesniam namų jungimui. „Taigi viena gyvenamųjų namų serija respublikos sostinè buvo statoma 10 metų!" (Parčiauskas 1982). Antroji priežastis - tai nedidelis apdailos medžiagų asortimentas, spalvinio ịvairumo stoka, nes paprasčiausiai nebuvo pasiūlos. Karoliniškių ir Viršuliškių projektuose buvo numatytas spalvinis pastatų sprendimas pagal pastatų aukštị arba zoną mikrorajone. Tačiau realizuojant projektus, Karoliniškèse liko tik tamsiai raudonos spalvos ugniasienès (kurios kritikuotos kaip pernelyg apsunkinančios vaizdą (Minkevičius, Rymeikis 1977), o Viršuliškèse ryškių spalvų nėra. Šeškinès atvejis panašus - vietoje planuotos švarios baltos fasadu spalvos igyvendinama pilka, todèl rajonas atrodo niūrus vien dèl to, kad tuo metu Statybos kombinatas pritrūko balto granito grūdelių (Šileika 1980). Nesèkmių priežastimi taip pat įvardijama žemoka statybos darbų kokybė, kaip ir užmirštos mažosios architektūros formos, ivairesni fasadų reljefiniai elementai. Tačiau svarbiausia tai, kad

\footnotetext{
2006 m. panaikintas Architektūros muziejus Vilniuje (išsamus šio muziejaus istorijos ir likimo aprašymas M. Baužienès straipsnyje „Neatšvęstas Architektūros muziejaus keturiasdešimtmetis" (Baužienè 2008)). Beveik 70000 jame sukauptų eksponatu, kuriu didelè dalis atspindèjo straipsnyje analizuojamą laikotarpi, šiandien saugomi Nacionaliniame muziejuje ir yra sunkai prieinami. Kita dalis aktualios medžiagos saugoma šiuos rajonus kūrusiu architektu asmeniniuose archyvuose; o kadangi nèra ir bendros bazès, kurioje sistemingai šie darbai galètų atsirasti, jų tyrimas ir viešinimas taip pat sudètingas, nors praejo tik 40 metų po „naujųjų“ rajonų formavimo pradžios.
}

projektai nekompleksiškai realizuojami (Balčiūnas 1977). Pažymima, jog tuo metu, ko gero, nebuvo gyvenamojo rajono pastatyto taip, kaip numatyta patvirtintuose projektuose.

8-ajame dešimtmetyje prasidejjusi gyvenamųjų rajonų monotonijos kritika vyko kartu su konkrečiais pasiūlymais, kaip to išvengti. Pirmoji priemonè - tai stambiaplokščiu gyvenamųjų namų serijos keitimas. Vilniuje statyti tos pačios serijos gyvenamieji namai tol, kol „<...> ieškojimų kelyje gimsta ir 1977 m. pilnai ìdiegiama naujoji serija - 120V“ (Stražnickas 1981). Tai trumpesnio žingsnio blokai, kurių „<...> fasadai bus plastiškesni ir išraiškingesni nei iki šiol statytujų. <...> Pagrindu paèmus blokus-sekcijas, komponuojamas iš įvairių tipų blokų-butų, galima suforminti išraiškingos architektūros namus, o kuriant kompleksus - įdomiai jungti sekcijinius pastatus" (Dyčmonas 1975). Kosmonautų prospekto aplinkoje pirmieji šio tipo namai pastatyti baigiamame formuoti Viršuliškių rajone (4 pav., c). Unikalu tai, kad naujosios serijos namai sujungiami ta pačia ažūrine plokšte, kuri kartota visame iki tol statytame rajone. Tokio tipo jungimo pavyzdys, žymintis naujojo rajonų formavimo etapo pradžią - vienintelis Kosmonautų prospekto aplinkoje.

\section{Šeškinès rajonas: naujoji namų serija ir monolitiniai aukštybiniai pastatai}

Apie 1977 m. projektuojamas Šeškinès gyvenamasis rajonas. Kosmonautų prospekto ašyje tai pirmasis rajonas, kuris visas formuojamas naujosios serijos $120 \mathrm{~V}$ namų grupemis. Trumpo žingsnio namai leido smulketi pastatų grupių išklotinèms, todèl ir visoje mikrorajonų struktūroje ryškesnis segmentiškumas (5 pav., d). Pastatų grupès visuose Šeškinès mikrorajonuose formuojamos „U“ ir „L“ raidžiu bei jų modifikacijų principu, taip kuriamos pusiau uždaros namų grupių vidinès erdvès. Palyginti su Karoliniškių tarpgrupinèmis erdvèmis, Šeškinèje jos stambesnès, tačiau ir aiškiau identifikuojamos. Erdvè formuojama trimis vertikaliomis pastatų plokštumomis, todèl šiame rajone laisvojo planavimo sprendiniai igyja kitokị charakterị.

Pagal Karoliniškių ir Viršuliškių namų grupių formas miesto plane galima atpažinti, jog tai du skirtingi rajonai; to paties negalima teigti lyginant Šeškinès, Justiniškių, iš dalies Fabijoniškių gyvenamuosius rajonus. Nèra ryškių skirtumų tarp šių rajonų gyvenamųjų namų grupių, 9-uoju-10-uoju dešimtmečiais formuotu iš serijos $120 \mathrm{~V}$ pastatų. Necharakteringas pastatu grupavimas plane, taip pat visuose rajonuose beveik visiškai identiška pastatu architektūrine išraiška ir vienodi architektūrinių detalių, reljefų motyvai. Taigi 


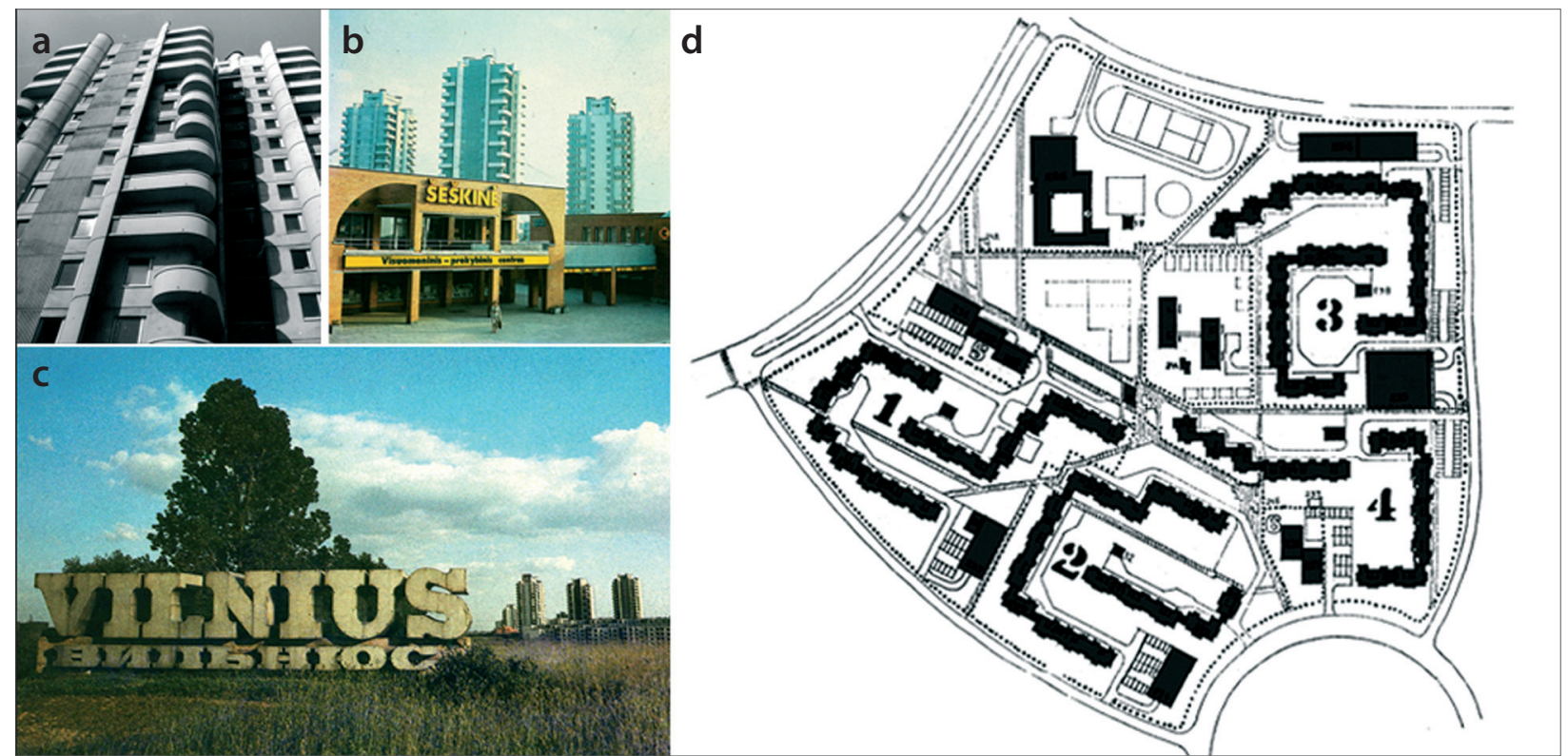

5 pav. Šeškinès monolitinio aukštybinio pastato fragmentas (a); vaizdas nuo rajono centro (b); vaizdas įvažiuojant į Vilnių (c); Šeškinès mikrorajono planas (d)

Fig. 5. Detail of monolithic concrete high-rise building in Šeškinè (a); view from the district centre (b); view from access to Vilnius (c); plan of Šeškinè microdistrict (d)

8-ojo dešimtmečio pradžioje kritikuotas Karoliniškiu rajonas, po jo suprojektuotos Viršuliškès tipinių gyvenamujų namų grupių atžvilgiu yra daug originalesnès nei vèliau formuoti gyvenamieji rajonai. Tačiau rajonu dominančių aspektu yra atvirkščiai.

8-ajame dešimtmetyje labiausiai atsilikta statant architektūrinius naujųjų rajonų akcentus - daugiaaukščius namus. Tuo metu dvylikos-šešiolikos aukštų namai Lietuvoje reikalingi ne miestų užstatymo intensyvumui didinti, bet negausioms naujai statomų rajonų dominantėms kurti. Architektūriniu požiūriu tos dominantès kiekviename stambesniame masyve turèjo būti skirtingos, tačiau tuo metu Lazdynuose, Viršuliškèse ir Karoliniškèse pastatyta daugiau kaip keturiasdešimt dvylikos aukštų dominančių pagal vieną ir tą pati projektą (Balčiūnas 1977). Taip net ir urbanistiniai akcentai praranda savo individualumą ir tampa stereotipais. Nesugebejjimo statyti įvairius daugiaaukščius priežastis utilitari - Namų statybos kombinatui įvairaus tipo stambiaplokščiu daugiaaukščiu namų gamyba buvo sunki užduotis, be to, be galo ilgas procesas tarp idejos ir igyvendinimo. Taigi antrąja gelbèjimosi nuo architektūrinès naujụjų rajonų monotonijos priemone įvardijamas monolitinis gelžbetonis, kurị naudojant kiekvienam naujai kuriamam rajonui pradedami projektuoti skirtingo architektūrinio charakterio daugiaaukščiai akcentai, kurių pirmieji Kosmonautu prospekte pastatomi jau suformuotuose Lazdynuose ir tada dar tebestatytoje Šeškinèje (5 pav., a-c).

Patys pirmieji Vilniuje eksperimentiniai monolitiniai daugiaaukščiai bendrabučiai pastatomi studentų miestelyje Saulètekyje 1972 m. (arch. B. Krūminis, konstr. J. Sidaravičius). Tai pirmasis bandymas su monolitiniu karkasu ir stambiaplokštèmis išorès sienomis (Parčiauskas 1982; Antanaitis 1984). Šiandien šis šešiu 16-os aukštu bendrabučių kompleksas yra vienas iš 11 urbanistikos paveldo objektu Vilniaus mieste, įrašytų ì Kultūros registrų sąrašus (UV-66, Saulètekio miestelis) (Kultūros... 2007).

Nuo 1979 m. pradèti statyti gyvenamieji namai, kuriu pirmieji atsirado jau suformuotuose Lazdynuose. Rajono suplanavimo projekte buvo numatytos vietos šiems objektams. Naujieji monolitiniai pastatai ne tik atlieka rajonų vertikaliųjų dominančių misiją, bet ir „teikia rajonams individualumo. Labai svarbus jų vaidmuo formuojant urbanistinių kompleksų kompoziciją, siluetą" (Balčiūnas1984). Monolitinè statyba laikyta pranašia ne tik kaip galimybe įvairinti rajonų charakterí, bet ir padejo spręsti gana utilitarius klausimus. Ji turëjo tapti pagrindine priemone mažinant industrinès statybos apimti, nes „techniniu ir ekonominiu požiūriu ji yra racionalesnë“ (Rusteika 1979). Kartu su 1983 m. Šeškinejje pradètais statyti trylikos 


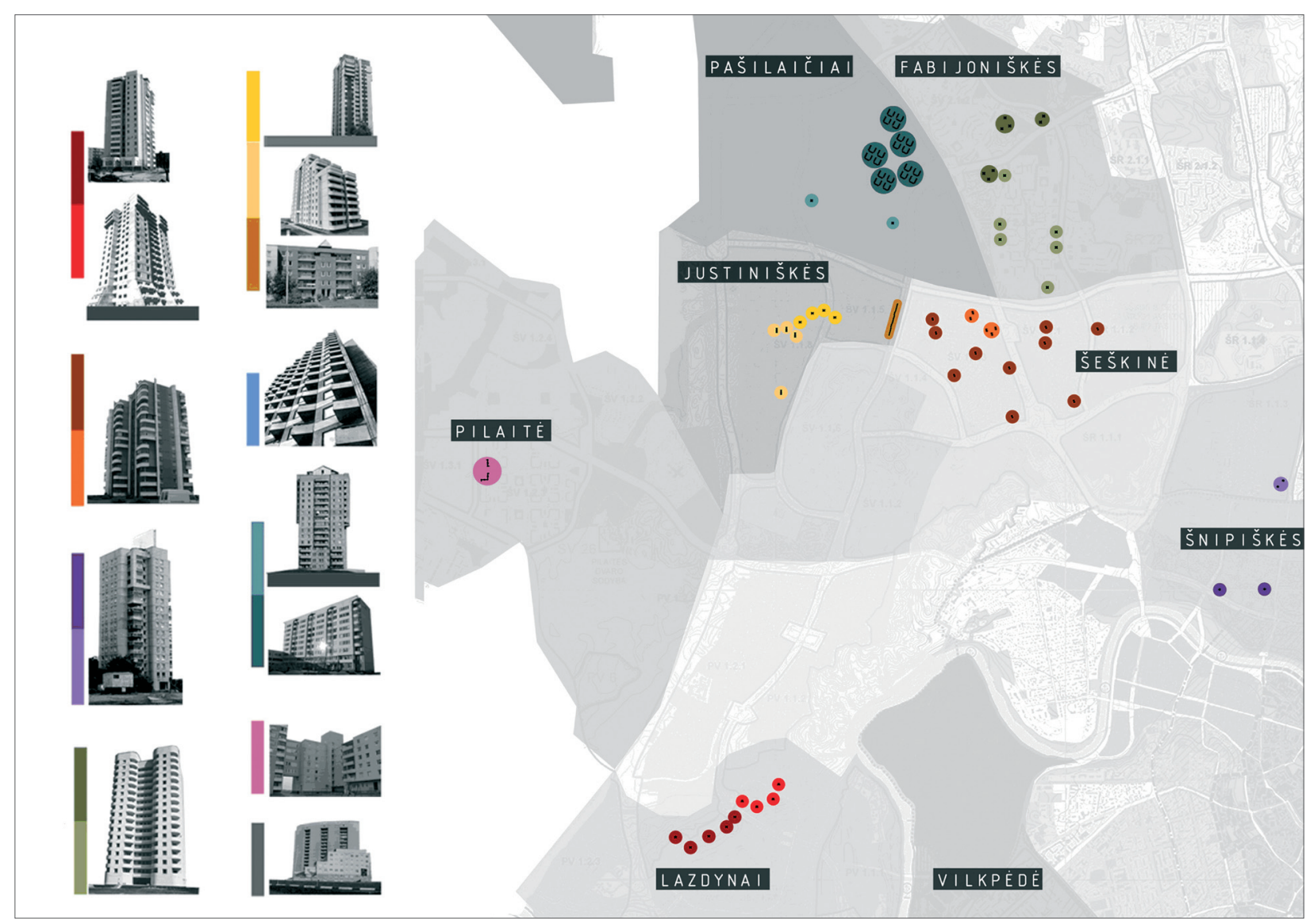

6 pav. Sovietinių metų monolitinių gyvenamųjų namų tipai Vilniuje ir jų vieta (schema autorès)

Fig. 6. Types of soviet period monolithic high-rise dwelling buildings and their location in Vilnius

ir šešiolikos aukštų monolitiniais gyvenamaisiais pastatais (arch. B. Krūminis, D. Ruseckas) pradedama plètoti apvalių architektūrinių detalių tema, kuri buvo nauja industrineje stačiakampių aplinkoje. 9-ajame dešimtmetyje Šeškine kartu su monolitiniu miesto pavadinimo ženklu žymèjo Vilniaus miesto pradžią. Šeškinès panorama su monolitiniais aukštybiniais pastatais pirmajame plane buvo vienas pirmųjų vaizdų ịvažiuojant ị miestą nuo Rygos plento (Ruseckas 1987) (5 pav., c).

Pasitvirtinus pirmiesiems lūkesčiams dèl monolitinių pastatų svarbos, 9-ojo dešimtmečio pradžioje įkuriama Vilniaus monolitinès statybos valdyba ir prasideda individualių monolitinių taškų dèliojimas kiekviename naujai projektuojamame rajone. Šiame lauke lietuviai vèl sulaukia sajunginio pripažinimo už originalumą. Monolitai ilgainiui tampa (tarp)rajoniniais orientyrais arba identifikaciniais ženklais erdveje. Šiandien Vilniuje yra apie devyniasdešimt šešiolikos tipų daugiaaukščių monolitinių pastatų Saulètekyje, Lazdynuose, Šeškinejje,
Justiniškėse, Fabijoniškèse, Pašilaičiuose ${ }^{4}$, Vilkpèdejje, Pilaitèje, Šnipiškèse ir Naujojoje Vilnioje (Čiurlionienè 2009) (6 pav.). Kiekviename iš šių rajonų stovi 1-2 tipų monolitiniai aukštybiniai pastatai ${ }^{5}$, kurie nebekartojami kituose Vilniaus rajonuose ${ }^{6}$, taigi šiuos objektus būtų galima pavadinti „rajonų vardiniais ženklais“. Būtent šie žaidimai netipiniais pastatais kaip rajonų atpažinimo ženklais iš dalies neigia tipiškumo prielaidą kai kuriuose sovietinių metų gyvenamuosiuose rajonuose Vilniuje.

${ }^{4}$ Pašilaičiuose realizuoti vieni iš paskutinių sovietinių metų monolitinių namų kompleksai (arch. D. Ruseckas, I. Maknienè). Šiame rajone yra du monolitiniu pastatu tipai: a) 16-os aukštu dominantès (arch. R. Beinortas); b) 9-ių ir 3-jų aukštų pastatų grupès, pusiau perimetriniu užstatymu supančios vidinius kiemus. Keturiu grupiu kompleksas sudaro kvartalą su jam priklausančiomis viešosiomis erdvèmis.

${ }^{5}$ Šiuo atveju to paties projekto, bet skirtingo aukštingumo pastatai ivardijami kaip atskiras tipas. Visiškai skirtingu dvieju projektų monolitiniai pastatai stovi tik Pašilaičiuose, Justiniškèse ir Lazdynuose.

${ }^{6}$ Pagal kelis iš šių projektų vèliau pastatyti gyvenamieji namai kituose Lietuvos miestuose. 

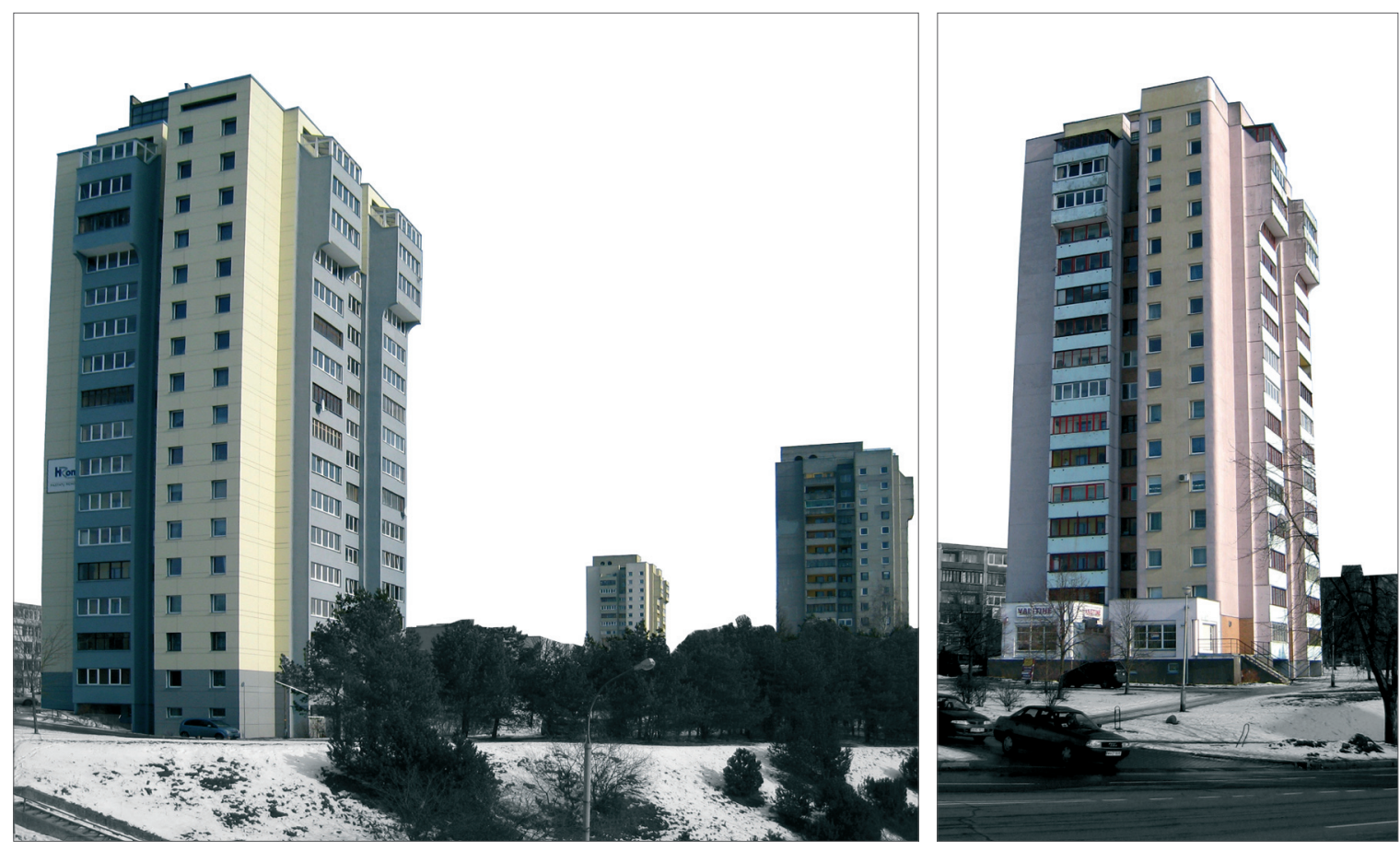

7 pav. Atnaujintų daugiaaukščių Lazdynuose vaizdas (nuotrauka autorès)

Fig. 7. View of high-rise buildings after renovation in Lazdynai

\section{Sovietinio laikotarpio gyvenamųjų rajonų atnaujinimo problematika}

Šiandieninis sovietinių metų rajonų atnaujinimas sukuria paradoksalią situaciją, kai rajonų netipiniai objektai praranda savo pirminius bruožus, ir anksčiau buvęs netipinis objektas tampa šiandieniu tipiniu. Tai pastebima rajonų plano struktūros pokyčiuose. Vilniaus miesto sovietinių gyvenamųjų rajonų tankinimą reglamentuoja Vilniaus miesto Bendrasis planas iki 2015 m.: „nauja statyba, tankinanti šių rajonų gyvenamųjų teritorijų užstatymą, galima tik tuo atveju, jei tai numatyta kompleksiniuose jų renovacijos projektuose ir yra tiesiogiai susieta su teritorijos revitalizacija“ (Vilniaus miesto... 2007). Smulkiau nenagrinejjant, ar naujieji objektai atgaivina rajoną, ar ne, šiuose rajonuose tankinimo procesas vyksta pagal kelias tendencijas. Nauji objektai visiškai suformuotame rajone statomi: a) pagal pirminę rajono suplanavimo koncepcijos plano schemą, keičiant tik erdvinę-tūrinę struktūrą, b) ne pagal pirminę rajono suplanavimo koncepciją, keičiant ir plano, ir erdvinę struktūrą (Čiurlionienè 2009). Abiem atvejais tipinių pastatų ir jų grupių kombinacijų savitumas kinta. Tipiniai pastatai nèra tie objektai, kurių architektūra turètų išliekamąją vertę (tiek dèl tipinio projekto, tiek dèl jų kiekio mieste) ir kurie „<...> dèl savo masišku- mo vargu ar gali būti išsaugoti in corpore. Tačiau istoriniu požiūriu būtų svarbu miesto audinyje fiksuoti šių fenomenų pradžią (pavyzdžiui, pirmasis blokinis namas ir pan.) ar specifiškumą SSRS kontekste $<\ldots>$, tipiškiausius arba, priešingai, „nuo normos nukrypusius" atvejus" (Čepaitienè 2004). Tačiau kombinuojant tipines industrines „kaladèles“ plane ir erdveje kurtos charakteringos rajonų kompozicijos, kurios tiek miesto plane, tiek trimatėje erdveje nèra tipinis reiškinys. Gal būtų galima svarstyti pastatų grupių (kurių kombinacija specifiškai būdinga tik vienam rajonui) nepakitusios urbanistinès struktūros išsaugojimą tokiu atveju, kai visas rajonas nebetenka savo pirminio charakterio dèl pokyčių ${ }^{7}$. Norint išsaugoti pastatų grupę kaip savotišką ansambli, susiduriama su nekontroliuojama architektūrinio chaoso problema keičiant jų architektūrinius bruožus. Sovietiniais metais gyvenamųjų namų grupių ansamblio spalvinis vientisumas ịvardintas kaip teigiamas reiškinys. „Vilniuje kiekvienas gyvenamasis

\footnotetext{
${ }^{7}$ Kaip, pvz., Žirmūnų I-asis mikrorajonas įtrauktas ị urbanistinių paminklų sąrašą (UV 63), tačiau, skirtingai nuo Lazdynų, Vilniaus miesto bendrajame plane apsaugos statusas šiam dariniui nesiūlomas, „kadangi buvusio Zirmūnų mikrorajono $\langle\ldots\rangle$ pirminè urbanistine struktūra didžiąja dalimi yra pakitusi“ (Kultūros... 2007).
} 
rajonas, net kai jis statomas skyrium, sprendžiamas kaip vieningas polichromines kompozicijos vienetas. $<\ldots>p a-$ sirinkus pernelyg smulku spalvinio zonavimo vieneta, nukenčia bendra masyvo planinès-erdvinès kompozicijos idejja" (Minkevičius, Rymeikis 1977). 2004 m. St „Vilniaus planas“ parengtose rekomendacijose būsto ir gyvenamosios aplinkos renovacijai (SI „Vilniaus..." 2004) teigta, kad „renovuojamiems namams parenkant fasadu spalvas neskaidyti gyvenamujų rajono kvartalų, kiekvieną namą dažant kitaip, bet stengtis sukurti skirtingų spalvų namų grupes. Būtent kompleksinis spalvinis sprendimas padètų sukurti kvartalo identitetą". Tačiau realūs renovacijos rezultatai kitokie: neretu atveju tipiniai namai renovuojami pagal skirtingus projektus, ir tas pats namo tipas gali atrodyti visiškai skirtingai net toje pačioje namų grupeje. Taip prarandamas dar vienas rajono „vardinio ženklo“ - savitų namų grupių kombinaciju - vientisumas. Renovacijos procesuose dingsta ir identifikaciniai dekoratyviai elementai. Ugniasienių, laiptinių ornamentiniai reljefai dažniausiai uždengiami šiltinant sienas, mažosios architektūros formos landšafte keičiamos naujomis tipinemis ${ }^{8}$.

Monolitinių akcentų architektūrinès išraiškos originalumas taip pat kinta. „Renovacijos sąlygos vienodai taikomos ir mažaaukščiams pastatams, ir daugiaaukščiams monolitiniams akcentams, nors šių objektų renovacija skiriasi technologiniu, tuo pačiu ir finansiniu požiūriu“ (Čiurlionienè, Ruseckas 2009). Finansavimo sąlygos tos pačios, todèl ir rezultatas adekvatus. Pirmieji pavyzdžiai jau realizuoti etaloniniuose Lazdynuose (7 pav.). Trys iš keturių to paties tipo monolitiniai daugiaaukščiai renovuoti pagal visiškai skirtingus projektus, pagal kuriuos vienas perdažytas rausva spalva, kitas dengtas žalsvomis, o trečiasis - gelsvomis fasadu apdailos plokštemis. Trys objektai - trys galimi variantai, o gautas rezultatas skatina gana kontraversiškai vertinti šią įvairovę, kuri ypač ryškiai matoma pietvakarinèse miesto panoramose. Šioje situacijoje prarandamas rajono erdvinès kompozicijos vientisumas, taip pat ir architektūrinès detalès, kurios renovuojant pagal tipinę technologija paprasčiausia pasislepia, o tai keičia šių objektų architektūrinę išraišką.

\footnotetext{
${ }^{8}$ Prasidejus monolitinès statybos bangai, neretai mažosios architektūros formos kurtos pagal tą pačią technologiją kaip skulptūros, pvz., vaikų žaidimų aikštelių elementai. Jungiant keletą vienodu betoniniu segmentu i grupes, gaunamos ažūrinès erdvinès sienelès arba savotiški maži statiniai. Pradejus mikrorajonų viešuju erdviu renovaciją, šie objektai dingsta ir ju vietoje statomi tipiniai vaikų žaidimų aikštelių įrenginiai (Justiniškių pavyzdys).
}

Taip kritikuojama industrinès statybos rajonų architektūrinè monotonija keičiama šiandienine monotonija, kai niveliuojamas skirtumas tarp sovietinio laikotarpio ir šiandienių naujųjų gyvenamųjų rajonų, nes vakarykštis netipinis objektas tampa šiandieniu tipiniu.

\section{Išvados}

1.Po 1960-ujų metų planuojant naujuosius gyvenamuosius rajonus Vilniuje prasidejo savitumo paieškos urbanistinèje struktūroje, realizuotos Žirmūnu, Lazdynų, Karoliniškių, Viršuliškių, Šeškinès ir kituose mikrorajonuose. Šie urbanistiniai dariniai Vilniuje yra paskutiniai tokio masto vientisos ir autorinès urbanistinès kompozicijos pavyzdžiai.

2. Nagrinejjant gyvenamuosius rajonus, paaiškejja, jog po Lazdynų suplanuotuose Karoliniškių, Viršuliškių ir Šeškinès rajonuose ryškiausiai atsiskleidžia šių teritorijų formavimo priemonių kaita:

a) 7-ajame dešimtmetyje, 8-ojo dešimtmečio pradžioje ieškota originalių rajonų suplanavimo sprendimų naudojant tuos pačius tipinès architektūros pastatus, kiekviename rajone juos savitai komponuojant erdveje, pastatus ir aplinką marginant ornamentais, būdingais tik vienam rajonui (Karoliniškèms ir Viršuliškèms). Šio laikotarpio urbanistiniai-architektūriniai sprendimai sulaukè kritikos dèl 1) nepakankamo erdvinio suplanavimo originalumo, kurio pagrindine priežastimi buvo neišraiškingas reljefas (skirtingai nuo Lazdynų); 2) klaidumo; 3) projektų ir realizacijų neatitikimo; 4) nepakankamos spalvų ir medžiagų ívairovés; 5) ilgalaikio tų pačių tipinių projektų kartojimo;

b) atsižvelgiant ị šią kritiką, 8-ojo dešimtmečio pradžioje pradèdami keisti tipinès architektūros erdviniai parametrai (pirmoji tokio tipo namų grupe Viršuliškèse ir visas Šeškinès rajonas). Rajonai formuojami trumpo žingsnio sekciniais pastatais. Tačiau dèl susmulkèjusios struktūros nebę̨manomas charakteringas pastatu grupavimas, rajonams būdinga beveik identiška pastatų architektūrinè išraiška ir vienodi architektūrinių detalių, reljefų motyvai;

c) siekiant išvengti naujo pobūdžio urbanistinès ir architektūrinès monotonijos 8-ojo dešimtmečio pabaigoje gyvenamųjų rajonų identitetas ir originalus charakteris pradètas kurti specialiai jiems projektuojamais aukštybiniais monolitiniais akcentais (Šeškinè). Vilniuje pastatyta apie devyniasdešimt šešiolikos tipų daugiaaukščių 
monolitinių pastatų. Kiekviename rajone stovi tik jam projektuoti aukštybiniai pastatai, kurie nebekartojami kituose miesto rajonuose, taigi šiuos objektus būtų galima pavadinti „rajonų vardiniais ženklais“.

3. Grupuodami tipinius pastatus specifine forma, kurdami netipines dekoratyvines detales, unikalius monolitinius gyvenamuosius pastatus urbanistai ir architektai siekè įdiegti „vardinių arba identifikacinių ženklų“ sistemą kiekviename naujame gyvenamajame rajone. Ši netipinių objektų sistema iš dalies paneigia sovietinių metų gyvenamųjų rajonų tipiškumą. Kaip vertingus ir netipinius gyvenamujų rajonų Vilniuje bruožus galima ịvardinti: a) rajono urbanistinès struktūros savitumą ir kompozicinị vientisumą; b) tipinių pastatų grupių kombinacijų savitumą; c) daugiaaukščiu monolitinių gyvenamụjų pastatų architektūrinès išraiškos originalumą; d) rajonų teritorijų „erdvumą“.

4. Pastaraisiais metais Vilniaus miestui plečiantis naujose teritorijose ir įsisavinant vidines, sovietiniu laikotarpiu formuoti, rajonai pradeti tankinti ir renovuoti. Kai kuriais atvejais šie pokyčiai yra problemiški dèl ittakos išskirtiems nagrinėjamų struktūrų bruožams.

5. Rajonų urbanistinès struktūros savitumas ardomas atsirandant naujiems objektams, kurie keičia rajonų erdvumą ir kai kuriais atvejais viešosios erdvès paskirti. Dalies pavienių pastatų renovacija vykdoma pagal skirtingus projektus, dèl to rajonuose atsiranda chaotiškumo ịspūdis, keičiantis rajono architektūrini vientisumą. Vertikalių akcentų architektūrinè vertė keičiasi juos modernizuojant pagal skirtingus projektus, kurie keičia šių objektų išraiškingas architektūrines detales.

6. Minèti pokyčiai gali turèti įtakos netipinio rajonų charakterio niveliacijai ir urbanistinès struktūros išliekamajai vertei. Kai kurių rajonų išliekamoji vertè hipotetinè ir reikalauja atitinkamo urbanistinès struktūros kokybinio tyrimo, kuriuo remiantis būtu galima išsamiau nagrinèti šių rajonų bei jų atskirų segmentų ar objektų apsaugos galimybes tolesniuose rajonų atnaujinimo ir plètros procesuose.

\section{Literatūra}

Antanaitis, J. 1984. Monolitinei statybai - naujus projektus ir efektyvesnes medžiagas, Statyba ir architektūra 11(306): 4-5.

Balčiūnas, V. 1977. Kokie bus mūsų daugiaaukščiai namai, Statyba ir architektūra 11(222): 8-11.

Balčiūnas, V. 1984. Monolitinè statyba, Statyba ir architektūra 2(297): 4-6.

Balènas, K. 1970. Atbilda statybininkai į Karoliniškes, Statyba ir architektūra 2(122): 4-6.

Balènas, K. 1975. Televizijos ir radijo laidų perdavimo stoties bokšto statyboje, Statyba ir architektūra 4-191: 6-9.
Baužienè, M. 2008. Neatšvęstas Architektūros muziejaus keturiasdešimtmetis, Kultūros barai 2008(9): 30-34.

Budrys, J. 1976. Karoliniškès šiandien ir rytoj, Statyba ir architektūra 2(201): 6-9.

Čepaitienè, R. 2004. Sovietinio laikotarpio istorijos ir paveldo iprasminimo problemos Vilniaus mieste, iš Santykis su istorine praeitimi XXI amžiaus Vilniuje, 47-59.

Čiurlionienè, I. 2009. Sovietmečio gyvenamųjų rajonų erdvinès struktūros kaita (Vilniaus miesto pavyzdys), iš Subalansuotos plètros ideju raiška architektūroje ir teritoriju planavime. Vilnius. 104-117.

Čiurlionienè, I.; Ruseckas, D. 2009. Aukštybinių monolitinių pastatų renovacijos Vilniuje specifika, iš Būsto modernizavimas: nuo pastato remonto iki miesto at(si)naujinimo. Santraukų rinkinys. Vilnius, 8-9.

Čyžius, J.; Vanagas, A. 1970. Karoliniškes pavadinkime Šaltūnais, Statyba ir architektūra 4(124): 32.

Dyčmonas, J. 1975. Naujos serijos stambiaplokštis namas, Statyba ir architektūra 12(199): 6-9.

Dremaite, M. 2010. Lazdynai, Living and Dying in the Modern Urbanity. Denmark, Estonia, Finland, Iceland, Latvia, Lithuania, Norway, Sweden. Nordic- Baltic Experience. Docomomo. Published The Royal Danish Academy of Fine Arts, School of Architecture in cooperation with Chalmers University of technology, 106-107.

Jaralovas, J. 1979. Tipiniai namai. Ar dar ilgam?, Statyba ir architektūra 1-236: 10.

Jaralovas, J. 1975. Kiekvienam kompleksui - savitą veidą, Statyba ir architektūra 1(188): 3-8.

Kultūros vertybès. Vilniaus miesto Bendrasis planas iki 2015. Aiškinamasis raštas. 2007. Vilnius [žiūrèta 2010 m. lapkričio 15 d.]. Prieiga per internetą: <http://www.vilnius. lt $/$ bplanas/download.php?file_id=66 $>$.

Minkevičius, J.; Rymeikis, A. 1977. Miestas ir jo spalvos, Statyba ir architektūra 8(219): 4-6.

Miškinis, A. 1982. Lietuvos miestų architektūros savitumai: kūrybos pozicija, Statyba ir architektūra 11(282): 12.

Miškinis, A. 1991. Lietuvos urbanistika: istorija, dabartis, ateitis. Vilnius: Mintis.

Moussavi, F.; Kubo, M. 2008. The Function of Ornament. Harvard University Graduate School of design: 2008.

Parčiauskas, V. 1982. Miestai - kaip žmonės, Statyba ir architektūra 4(275): 4-5.

Ruseckas, D. 1987. Monolitas. Vilnius.

Rusteika, J. 1979. Monolitinès statybos perspektyva, Statyba ir architektūra 7(242): 20-21.

SI „Vilniaus planas“, 2004. Rekomendacijos būsto ir gyvenamosios aplinkos renovacijai. Vilnius.

Stražnickas, J. 1981. Stambiaplokštė statyba. Kas laimèta ir prarasta?, Statyba ir architektūra 8(267): 4-7.

Šileika, V. 1980. Vilniaus namų statybos kombinatas: vakar, šiandien ir rytoj..., Statyba ir architektūra 12(259): 2-3.

Vilniaus miesto Bendrasis planas iki 2015. 2007. Aiškinamasis raštas. Kultūros vertybès. Vilnius [interaktyvus], [žiūrèta 2010 m. lapkričio 15 d.]. Prieiga per internetą: $<$ http:// www.vilnius.lt/bplanas/download.php?file_id=66>.

Ванагас, Ю. 1974. Социологический эксперимент в формировании жилой среды, Архитектура СССР 11(1974): 13-14. 
Микучанис, В. 1974. Градостроительное мастерство, Архитектура СССР 11(1974): 6-9.

Новиков, Е.; Аникеев, А. 1978. Проблемы улучшения качества планировки и застройки новых городов, Архитектура СССР 2(1978): 28-45.

Полторацкий, Е.; Васильев, Н. 1977. Жилая среда - поиск индивидуальность, Архитектура СССР 9(1977): 31-35.

Сакалаускас, В. 1974. Красоту и удобства - на службу человека, Архитектура СССР 11(1974): 4-5.

Шешельгис, К. 1974. Особенности композиции жилого района Лаздинай, Архитектура СССР 11(1974): 18-19.

Яралов, Ю. 1974. Эксперимент продолжается..., Архитектура СССР 11(1974): 23-29.

\section{SOVIET PERIOD RESIDENTIAL DISTRICTS IN VILNIUS: PROBLEM OF TYPICAL CHARACTER}

\section{Ruseckaitè}

Abstract. In the fifties, the Soviet Union witnessed the start of the industrialised wave of massive construction of residential buildings, in the process whereof new urbanism structures emerged in cities and towns. In 1955-1990, the share held by them in Vilnius amounted to some $19 \mathrm{sq} \mathrm{km}$ and was called "The New Districts". Today, the aforementioned districts are referred to as typical faceless bedroom communities. It is the so-called grey face of social modernism or just an imperceptible background for the daily round, the typicality whereof is unquestioning. The report aims at arguing against the aforesaid statement providing a few features that demonstrate a nontypical character of these city districts. Wide appreciation, awards for planning Lazdynai and Žirmūnai districts, at least formal listing thereof as urbanism monuments keep from thoughtless application of the template "typical" for the other "new districts" either. The fact that the bedroom communities constitute a typical phenomenon in the former socialist countries is not denied, however, the emphasis on the differences between the districts is supposed to reveal the individual characters thereof. A few bedroom communities of Vilnius are analysed. The start is made from the thing incomprehensible at the present time in the real space of the districts, i.e. the plans and development history thereof. The circumstance that urbanism solutions of all the districts are works of authorship turns to one of the most important considerations. By courtesy of the art of ingenuity and by playing with typical cubes, different urbanism structures of each district are shaped. Freestyle games in the plains, games by the context on the mounds or just the Art of Ornamentation in the plan. This is the point where the features of Identification in the role of nontypicality of each district start showing up. They assist in orienting in the city plan identifying clearly the differences between the plans of districts. After shifting the research to the real space and to the present time, by capturing at the level of observer eyes, nontypical character of each district is disclosed through individual architectural details and monolithic concrete high-rise accents thereof. These objects become [inter]district guides or marks of Identification in the space. The paper states that these are the games by nontypical details and/or nontypical buildings in the role of marks of Identification that deny the myth of typicality partially. Current modernization of the districts of the soviet period, however, results in a paradoxical situation when the marks of Identification are leveled down and the former [Non] typical turns to today's Typical.

Keywords: soviet period, mass construction, typical buildings, monolithic concrete high-rise residential buildings.

\section{INDRE் RUSECKAITE்}

Master, PhD student, Dept and Fundamentals and Theory of Architecture, Vilnius Gediminas Technical University, Pylimo g. 26/Traku g. 1, 01132 Vilnius, Lithuania

E-mail:ruseckaite.indre@gmail.com

Master of Architecture, VGTU, 2005. Publications: author of several articles in popular professional and scientific magazines. Research interests: urban design, soviet period heritage, interdisciplinary research. Projects: author and co-author of several projects of urban design and architecture. 